\title{
Thermodynamic properties of water desorption in Buchenavia capitata (Vahl) Eichler
}

\author{
Hellismar W. da Silva ${ }^{1}$, Daniel E. C. de Oliveira ${ }^{2}$, Osvaldo Resende ${ }^{3}$ \& Lílian M. Costa ${ }^{4}$ \\ ${ }^{1}$ Universidade Federal de Lavras/Departamento de Agricultura. Lavras, MG. E-mail: waksonhellismar@gmail.com (Corresponding author) - ORCID: \\ 0000-0002-1353-2247 \\ ${ }^{2}$ Instituto Federal de Educação, Ciência e Tecnologia Goiano/Campus Iporá. Iporá, GO. E-mail: oliveira.d.e.c@gmail.com - ORCID: 0000-0002-3824-994X \\ ${ }^{3}$ Instituto Federal de Educação, Ciência e Tecnologia Goiano/Diretoria de Pesquisa e Pós-Graduação/Campus Rio Verde. Rio Verde, GO. E-mail: \\ osvresende@yahoo.com.br - ORCID: 0000-0001-5089-7846 \\ ${ }^{4}$ Instituto Federal de Educação, Ciência e Tecnologia Goiano/Campus Rio Verde. Rio Verde, GO. E-mail: lmctpg@yahoo.com.br - ORCID: 0000-0001- \\ 9195-8414
}

Key words:

latent heat

Gibbs free energy

theory of enthalpy-entropy

\begin{abstract}
A B S T R A C T
Thermodynamic properties provide information on energy demand and kinetic parameters in water sorption processes in agricultural products. Such information is essential to analyze and scale drying and storage equipment. The objective of this study was to determine the thermodynamic properties involved in the water desorption process in Buchenavia capitata (Vahl) Eichler seeds with moisture contents ranging from 13.31 to $7.21 \%$ dry basis (d.b.), obtained by the indirect static method, at temperatures of $10,20,30$ and $40{ }^{\circ} \mathrm{C}$. The latent heat of vaporization, differential entropy and Gibbs free energy increase with the reduction of the moisture content of the seeds. The enthalpy-entropy compensation theory is valid for the desorption process, which is controlled by the enthalpy. The desorption of water in the seeds is not a spontaneous process.
\end{abstract}

\section{Palavras-chave:}

calor latente energia livre de Gibbs relação entalpia-entropia

\section{Propriedades termodinâmicas de dessorção da água em sementes de Buchenavia capitata (Vahl) Eichler}

\section{R E S U M O}

As propriedades termodinâmicas fornecem informações sobre a exigência energética e parâmetros cinéticos nos processos de sorção da água em produtos agrícolas. Tais informações são essenciais para analisar e dimensionar equipamentos para secagem e armazenamento. Assim, objetivou-se, neste trabalho, determinar e analisar as propriedades termodinâmicas envolvidas no processo de dessorção da água de sementes de Buchenavia capitata (Vahl) Eichler com teor de água na faixa de 13,31 a 7,21\% base seca (b.s.), sendo estes obtidos pelo método estático indireto, nas temperaturas de $10,20,30$ e $40{ }^{\circ} \mathrm{C}$. O calor latente de vaporização, a entropia diferencial e a energia livre de Gibbs aumentam com a redução do teor de água das sementes. A teoria da compensação entalpia-entropia é válida para o processo de dessorção, sendo este controlado pela entalpia. A dessorção da água nas sementes é um processo não espontâneo. 


\section{INTRODUCTION}

The species Buchenavia capitata (Vahl.) Eichler (synonym of $B$. tetraphylla), popularly known in Portuguese as a "boca boa", is an emergent canopy tree with a natural occurrence in Neotropical forests from $23^{\circ} \mathrm{N}$ to $23^{\circ} \mathrm{S}$ (Weaver, 1991). Studies with the species demonstrated antioxidant, antimicrobial and, mainly, anti-HIV activities, whose properties were associated with alkaloids extracted from leaves (Beutler et al., 1992; Gramosa et al., 2010; Pottier et al., 2017).

Reduction of seed moisture content through drying is one of the most important factors in maintaining seed germination and vigor during storage (Silva et al., 2016). However, in order for the drying process to be carried out properly, it is necessary to know the forces and forms of binding of the water molecules with the active sorption sites of the product.

The sorption isotherms, which relate the hygroscopic equilibrium moisture content of a product with the relative humidity of the surrounding air (Costa et al., 2015) at constant temperature and pressure (Majd et al., 2013), are indispensable for defining the temperature and relative humidity of the air most suitable for storage (Chaves et al., 2015), as well as to determine the thermodynamic properties involved in the interaction between water and food components (Goneli et al., 2013), seeds and other agricultural products.

The latent heat of vaporization is defined as the amount of energy required to evaporate the water from the product (Corrêa et al., 1998). Enthalpy is an indication of the strength of the water vapor molecules interconnection with the active sorption sites (Oliveira et al., 2014b); and entropy is associated with the degree of disorder of water molecules (Goneli et al., 2010; Majd et al., 2013).

In this context, the aim in this study was to determine and analyze the thermodynamic properties related to water sorption in Buchenavia capitata (Vahl) Eichler seeds.

\section{Material ANd Methods}

The experiment was conducted out at the Post-Harvest Laboratory of Vegetal Products of the Federal Institute of Education, Science and Technology of Goiás - Campus of Rio Verde (IF Goiano - Campus Rio Verde), using seeds extracted from fruits of Buchenavia capitata (Vahl) Eichler, which were harvested manually and stored for seven days at room temperature. After extraction and cleaning, the seeds were dried under ambient conditions until reaching a moisture content of $13.16 \pm 0.17 \%$ (d.b).

In order to obtain the different moisture contents, the seeds were dried in an oven with forced air circulation at $45^{\circ} \mathrm{C}$ until reaching a moisture content of $12.06,9.60$ and $7.28 \%$ (d.b.), determined in an oven at $105 \pm 3{ }^{\circ} \mathrm{C}$ for $24 \mathrm{~h}$ (Brasil, 2009). Then, the water activity values, necessary to calculate the thermodynamic properties, were estimated by the Chung-Pfost model (Eq.1). This model showed satisfactory fit $\left(\mathrm{R}^{2}=0.988\right.$, mean relative error $=1.94 \%$, mean estimated error $=0.27$ ) when representing the desorption isotherms of $B$. capitata seeds at temperatures of $10,20,30$ and $40{ }^{\circ} \mathrm{C}$ and moisture content in the range of 7.21 to $13.31 \%$ (d.b.) (Costa et al., 2015). where:

** - significant at 0.01 level by t-test;

Xe - hygroscopic equilibrium moisture content, \% d.b.;

$\mathrm{T}$ - temperature, ${ }^{\circ} \mathrm{C}$; and,

$\mathrm{a}_{\mathrm{w}}$ - water activity, dimensionless.

To calculate the latent heat of vaporization of the water of the product $(\mathrm{L})$ for each condition of hygroscopic equilibrium moisture content of the seeds and for each temperature studied, Eq. 2 was used (Othmer, 1940).

$$
\operatorname{Ln}(\mathrm{Pv})=\frac{\mathrm{L}}{\mathrm{L}^{\prime}} \operatorname{Ln}(\mathrm{Pvs})+\mathrm{C}
$$

where:

Pvs - free water saturation vapor pressure, for a given equilibrium temperature (T), $\mathrm{kPa}$;

$\mathrm{Pv}$ - free water vapor pressure, for a given equilibrium temperature $(\mathrm{T}), \mathrm{kPa}$;

$\mathrm{L} \quad$ - product water vaporization latent heat, $\mathrm{kJ} \mathrm{kg}^{-1}$;

L' - free water vaporization latent heat, for a given equilibrium temperature, $\mathrm{kJ} \mathrm{kg}^{-1}$; and,

C - integration constant.

The values of the L/L' ratio (Eq. 2) were fitted to Eq. 3 for the enthalpy of water vaporization by Rodrigues-Arias (Brooker et al., 1992), including the parameter " $\mathrm{m}$ " to improve the estimates of L/L' (Corrêa et al., 1998). Then, Eq. 4 was used to calculate the latent heat of vaporization of the seed water at each temperature studied.

$$
\frac{\mathrm{L}}{\mathrm{L}^{\prime}}-1=\mathrm{a} \exp \left(-\mathrm{b} X \mathrm{e}^{\mathrm{m}}\right)
$$

$$
\mathrm{L}=(2502.2-2.39 \mathrm{~T})\left[1+\mathrm{a} \exp \left(-\mathrm{b} \mathrm{X \textrm {e } ^ { \mathrm { m } }}\right)\right]
$$

where:

$\mathrm{a}, \mathrm{b}, \mathrm{m}$ - coefficients that depend on the product.

The differential enthalpy, differential entropy, enthalpyentropy and Gibbs free energy, involved in the water desorption process in B. capitata seeds, were calculated using Eqs. 5, 6, 7 and 8, respectively (Beristain et al., 1996; Madamba et al., 1996; Nkolo Meze’e et al., 2008).

$$
\begin{gathered}
\ln \left(\mathrm{a}_{\mathrm{w}}\right)=\frac{\Delta \mathrm{h}_{\mathrm{st}}}{\mathrm{RT}_{\mathrm{a}}}-\frac{\Delta \mathrm{S}}{\mathrm{R}} \\
\Delta \mathrm{S}=\frac{\Delta \mathrm{h}_{\mathrm{st}}-\Delta \mathrm{G}}{\mathrm{T}_{\mathrm{a}}} \\
\Delta \mathrm{h}_{\mathrm{st}}=\mathrm{T}_{\mathrm{B}}(\Delta \mathrm{S})+\Delta \mathrm{G}_{\mathrm{B}} \\
\Delta \mathrm{G}=\mathrm{R} \mathrm{T}_{\mathrm{a}} \ln \left(\mathrm{a}_{\mathrm{w}}\right)
\end{gathered}
$$


where:

$\Delta \mathrm{h}_{\mathrm{st}}$ - differential enthalpy, $\mathrm{kJ} \mathrm{kg}^{-1}$;

$\mathrm{R}$ - universal gas constant $\left(0.287 \mathrm{~kJ} \mathrm{~kg}^{-1} \mathrm{~K}^{-1}\right)$, equal to $0.4619 \mathrm{~kJ} \mathrm{~kg}^{-1} \mathrm{~K}^{-1}$ for water vapor.

$\mathrm{T}_{\mathrm{a}} \quad$ - absolute temperature, $\mathrm{K}$;

$\Delta S \quad$ - differential entropy, $\mathrm{kJ} \mathrm{kg}^{-1} \mathrm{~K}^{-1}$;

$\mathrm{T}_{\mathrm{B}} \quad$ - isokinetic temperature, $\mathrm{K}$;

$\Delta \mathrm{G}_{\mathrm{B}}$ - Gibbs free energy at isokinetic temperature, $\mathrm{kJ} \mathrm{kg}^{-1}$; and,

$\Delta \mathrm{G}$ - Gibbs free energy, $\mathrm{kJ} \mathrm{kg}^{-1}$.

In order to validate the enthalpy-entropy compensation theory, the Krug test (Eq.9) was applied to compare the isokinetic temperature $\left(\mathrm{T}_{\mathrm{B}}\right)$ with the mean harmonic temperature $\left(\mathrm{T}_{\mathrm{hm}}\right)$, whose approximate confidence interval (1- $\alpha ; 100 \%)$ for the isokinetic temperature was calculated by Eq. 10 (Krug et al., 1976a, b).

$$
\begin{gathered}
\mathrm{T}_{\mathrm{hm}}=\frac{\mathrm{n}}{\sum\left(\frac{1}{\mathrm{~T}}\right)} \\
\mathrm{T}_{\mathrm{B}}=\hat{\mathrm{T}}_{\mathrm{B}} \pm \mathrm{t}_{\mathrm{m}-2, \mathrm{a} / 2 \sqrt{\operatorname{Var}\left(\mathrm{T}_{\mathrm{B}}\right)}}
\end{gathered}
$$

where:

$$
\begin{array}{ll}
\mathrm{n} & \text { - number of temperatures used; and, } \\
\mathrm{m} & \text { - number enthalpy-entropy data pairs. }
\end{array}
$$

\section{Results AND Discussion}

The values of water activity estimated by the Chung-Pfost model (Eq.1), for the temperatures of 10, 20, 30 and $40^{\circ} \mathrm{C}$ and for hygroscopic equilibrium moisture content in the range of 13.31 to $7.21 \%$ (d.b.) ranged from 0.6802 to 0.3255 (Table 1 ).

The decrease in moisture content and temperature promoted the reduction of water activity (Table 1 ), showing that the seeds of $B$. capitata become more stable for low water storage and lower temperature. Similar results were observed

Table 1. Values of water activity (dimensionless) estimated by the Chung-Pfost model as a function of temperature and moisture content of hygroscopic equilibrium of $B$. capitata (Vahl) Eichler seeds

\begin{tabular}{ccccc}
\hline Moisture content & \multicolumn{4}{c}{ Temperature $\left({ }^{\circ} \mathbf{C}\right)$} \\
\cline { 2 - 5 } (\% d.b.) & $\mathbf{1 0}$ & $\mathbf{2 0}$ & $\mathbf{3 0}$ & $\mathbf{4 0}$ \\
13.31 & 0.5766 & 0.6112 & 0.6457 & 0.6802 \\
13.29 & 0.5760 & 0.6105 & 0.6451 & 0.6796 \\
13.03 & 0.5679 & 0.6024 & 0.6369 & 0.6714 \\
12.99 & 0.5667 & 0.6012 & 0.6357 & 0.6703 \\
12.19 & 0.5404 & 0.5750 & 0.6095 & 0.6440 \\
12.08 & 0.5367 & 0.5712 & 0.6058 & 0.6403 \\
12.06 & 0.5361 & 0.5706 & 0.6051 & 0.6397 \\
11.93 & 0.5317 & 0.5662 & 0.6007 & 0.6353 \\
9.67 & 0.4459 & 0.4804 & 0.5149 & 0.5494 \\
9.63 & 0.4439 & 0.4785 & 0.5130 & 0.5475 \\
9.62 & 0.4436 & 0.4781 & 0.5126 & 0.5471 \\
9.49 & 0.4381 & 0.4727 & 0.5072 & 0.5417 \\
7.34 & 0.3330 & 0.3675 & 0.4020 & 0.4366 \\
7.31 & 0.3310 & 0.3655 & 0.4001 & 0.4346 \\
7.25 & 0.3280 & 0.3626 & 0.3971 & 0.4316 \\
7.21 & 0.3255 & 0.3601 & 0.3946 & 0.4291 \\
\hline
\end{tabular}

for seeds of 'tucumã-de-Goiás' (Astrocaryum huaimi Mart.) with moisture content in the range of 12.83 to $3.55 \%$ (d.b.) (Oliveira et al., 2014a) and jatropha (Jatropha curcas L.) with moisture content between 11.42 and $5.61 \%$ (d.b.) (Chaves et al., 2015), both at temperatures of $10,20,30$ and $40^{\circ} \mathrm{C}$.

The values of the $\mathrm{L} / \mathrm{L}$ ' ratio are indirectly proportional to the moisture content of the B. capitata seeds, whose lowest value (1.09), obtained for the highest moisture content (13.31\% d.b.), is higher than 1 (Figure 1A). These results indicate that the energy required to evaporate the water bound to the active sites of the product is always greater than the energy required to evaporate the pure water, as was also observed for seeds of 'tucumã-de-Goiás' (Oliveira et al., 2014a), jatropha (Chaves et al., 2015), pequi diaspores (Sousa et al., 2016) and baru fruits (Resende et al., 2017).

To estimate the latent heat of vaporization of the water contained in the B. capitata seeds for each temperature and moisture content range, Eq. 3 was fitted to the experimental data of the L/L' ratio (coefficient of determination of 0.999 ) and the values of the coefficients "a", "b" and "m" were substituted in Eq. 4, obtaining Eq. 11.

$\mathrm{L}=(2502.2-2.39 \mathrm{~T})\left[1+0.04331^{* *} \exp \left(6.75104^{* *} \mathrm{Xe} \mathrm{e}^{\left(-0.84611^{* *}\right)}\right)\right]$

where:

* - significant at 0.01 level by t-test
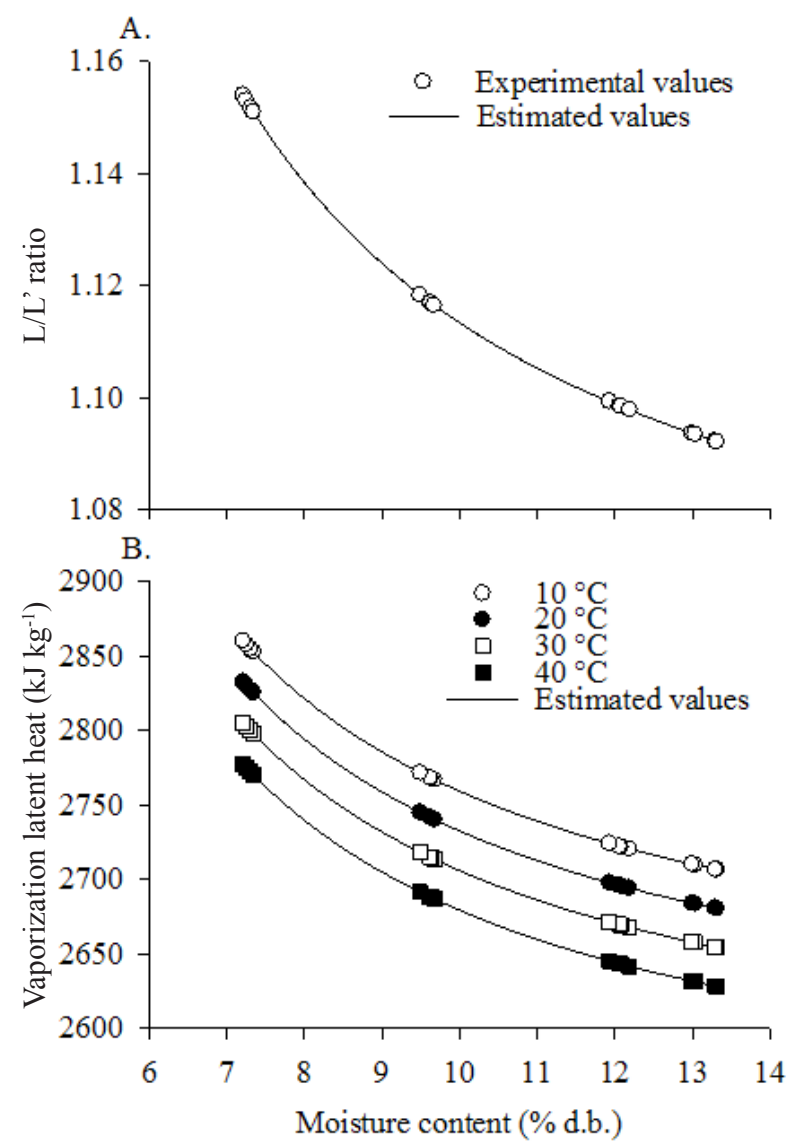

Figure 1. Experimental and estimated values of $L / L^{\prime}(A)$ and the latent heat of vaporization of water $(B)$ as a function of the equilibrium moisture content of B. capitata (Vahl) Eichler seeds 
The latent heat of vaporization increases with the reduction of the moisture content of $B$. capitata seeds and reduces with increasing temperature (Figure 1B), following the trend of most agricultural products (Corrêa et al., 1998; Oliveira et al., 2014a; Chaves et al., 2015; Sousa et al., 2016).

The heat of vaporization is defined as the minimum amount of energy required to evaporate a unit of mass of water bound to the biological structure of agricultural products (Corrêa et al., 1998; Sousa et al., 2016). The latent heat of vaporization is influenced by temperature and, mainly, by the moisture content of the product (Brooker et al., 1992).

For the moisture content between 13.31 and $7.21 \%$ (d.b.) and temperatures of $10,20,30$ and $40^{\circ} \mathrm{C}$, the values of the latent heat of vaporization of $B$. capitata seeds ranged from 2,628.40 to $2,860.11 \mathrm{~kg} \mathrm{~kJ}^{-1}$ (Figure 1B). For 'tucumã-de-Goiás' seeds with moisture content in the range of 12.83 to $3.55 \%$ (d.b.) and jatropha seeds with moisture content between 13.42 and $5.61 \%$ (d.b.), the latent heat of vaporization ranged from 2,666.73 to 3,049.00 $\mathrm{kJ} \mathrm{kg}^{-1}$ (Oliveira et al., 2014a) and 2,495.56 to $2,762.92 \mathrm{~kJ} \mathrm{~kg}^{-1}$ (Oliveira et al., 2014b), respectively.

The results show that the reduction of moisture content of $B$. capitata seeds increases the differential entropy (Figure 2). This tendency is indicative that the degree of disorder of water (Goneli et al., 2010; Majd et al., 2013) increases with the reduction of the moisture content of $B$. capitata seeds.

The values of the differential entropy ranged from 225.48 to $377.11 \mathrm{~kJ} \mathrm{~kg}^{-1} \mathrm{~K}^{-1}$, being strongly related to the moisture content (Figure 2). It is known that for high moisture content of $B$. capitata seeds, the entropy decreases and has a tendency to remain constant, indicating that up to a certain moisture content the sorption process can be reversible (Madamba et al., 1996). This tendency is related to the mobility of the water molecules during the sorption process (Oliveira et al., 2014b), being observed under conditions of high water activity, that is, when the active sites of the product are filled with water, resulting thus in lower mobility of water molecules (Hassini et al., 2015).

The enthalpy-entropy compensation relationship, involved in the water desorption process in B. capitata seeds, showed a

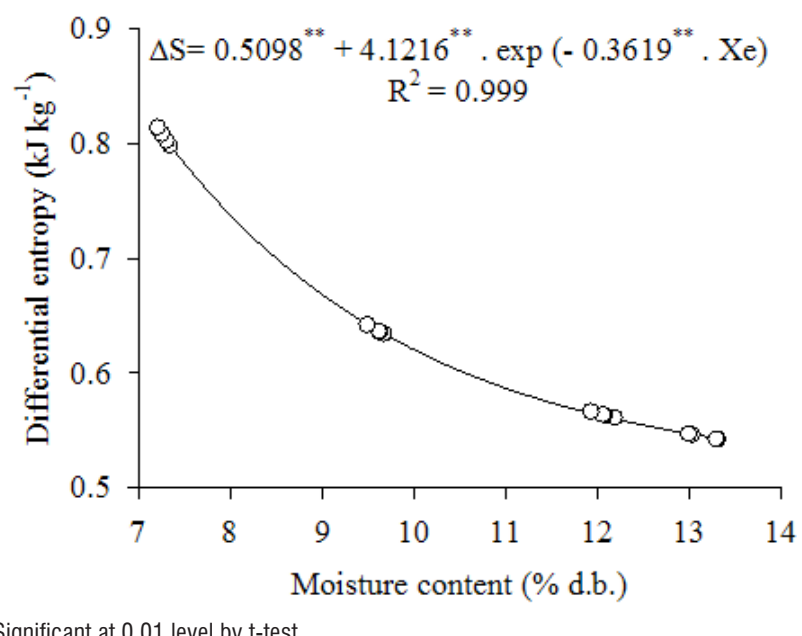

** Significant at 0.01 level by t-test

Figure 2. Experimental and estimated values of differential entropy of desorption as a function of the equilibrium moisture content of $B$. capitata (Vahl) Eichler seeds linear tendency with a high coefficient of correlation (0.997), suggesting the validity of the isokinetic theory, or enthalpyentropy compensation theory (Figure 3).

According to Krug et al. (1976a, b), linear chemical compensation exists only if the isokinetic temperature $\left(\mathrm{T}_{\mathrm{B}}\right)$ is different from the harmonic mean temperature $\left(\mathrm{T}_{\mathrm{hm}}\right)$. Thus, in the present study, the isokinetic temperature $(552.61 \mathrm{~K})$ is significantly different from the harmonic mean (292.35 K), since the calculated isokinetic temperature range was 528.09 to $577.12 \mathrm{~K}$. These results confirm the enthalpy-entropy compensation phenomenon, as well as suggest the existence of chemical and physical factors that react to the compensation theory (Beristain et al., 1996).

Another relevant information is the thermodynamic parameter that controls the sorption process of water in agricultural products. For this, Leffler (1955) proposed the following standards for the enthalpy-entropy relationship: if $\mathrm{T}_{\mathrm{B}}>\mathrm{T}_{\mathrm{hm}}$, the sorption process is controlled by enthalpy; if $\mathrm{TB}<$ $\mathrm{T}_{\mathrm{hm}}$, the process is controlled by entropy. However, $\mathrm{T}_{\mathrm{B}}(552.61 \mathrm{~K})$ is higher than $\mathrm{T}_{\mathrm{hm}}(292.35 \mathrm{~K})$, evidencing that the desorption process of water in B. capitata seeds is controlled by enthalpy, in agreement with works done for the majority of agricultural products (Beristain et al., 1996; Goneli et al., 2013; Oliveira et al., 2014a, b; Hassini et al., 2015; Resende et al., 2017).

The Gibbs free energy increases with the reduction of the moisture content of the seeds of B. capitata and with the reduction of the temperature (Figure 4 ). For the moisture content in the range of 13.31 to $7.21 \%$ (d.b.) and temperatures of $10,20,30$ and $40{ }^{\circ} \mathrm{C}$, Gibbs free energy ranged from 55.74 to $146.78 \mathrm{~kg} \mathrm{~kJ}^{-1}$.

The Gibbs free energy is related to the work required to make the sorption sites of the products available for attachment to water molecules (Nkolo Meze'e et al., 2008). Positive values characterize a non-spontaneous endergonic reaction, that is, one that requires an external agent supplying energy (Goneli et al., 2010). Thus, the positive values of the Gibbs free energy observed in Figure 4 indicate that the water desorption process in B. capitata seeds is not spontaneous.

The equations fitted to the Gibbs free energy values as a function of the moisture content of the B. capitata seeds can be used to estimate the energy required to make seed sorption

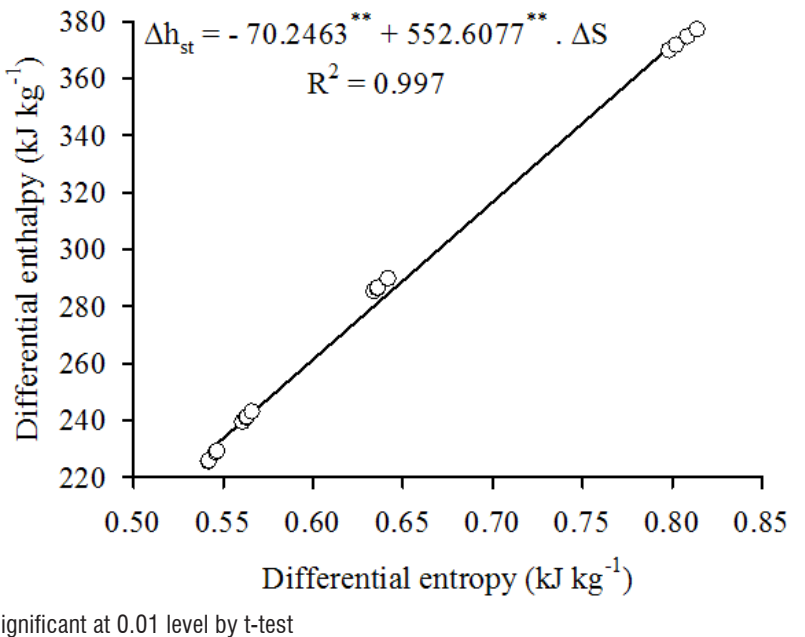

** Significant at 0.01 level by t-test

Figure 3. Enthalpy-entropy relationship for the water desorption process of $B$. capitata (Vahl) Eichler seeds 


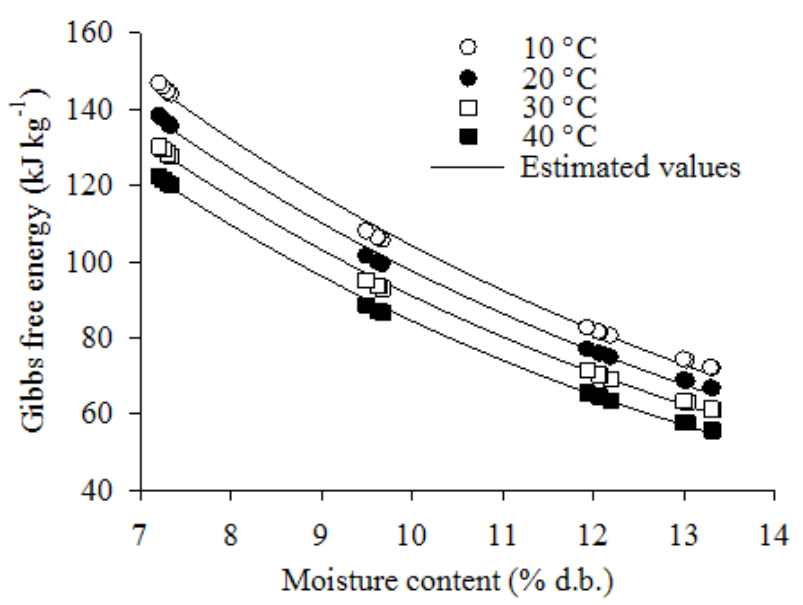

Figure 4. Gibbs free energy according to the moisture content of the seeds of $B$. capitata (Vahl) Eichler

Table 2. Regression equations for Gibbs free energy at different temperatures (T) and moisture content of $B$. capitata (Vahl) Eichler seeds

\begin{tabular}{ccc}
\hline $\mathrm{T}\left({ }^{\circ} \mathrm{C}\right)$ & Equation & $\mathbf{R}^{\mathbf{2}}$ \\
10 & $\Delta \mathrm{G}=342.5893^{* *} \exp \left(-0.1191^{* *} \mathrm{Xe}\right)$ & 0.996 \\
20 & $\Delta \mathrm{G}=329.4583^{* *} \exp \left(-0.1217^{* *} \mathrm{Xe}\right)$ & 0.997 \\
30 & $\Delta \mathrm{G}=319.0860^{* *} \exp \left(-0.1255^{* *} \mathrm{Xe}\right)$ & 0.998 \\
40 & $\Delta \mathrm{G}=311.2959^{* *} \cdot \exp \left(-0.1305^{* *} . \mathrm{Xe}\right)$ & 0.999 \\
\hline
\end{tabular}

" Significant at 0.01 level by t-test

sites available, since these equations had high coefficients of determination and significant regression parameters at 0.01 level by the t-test (Table 2).

\section{Conclusions}

1. The latent heat of water vaporization, differential entropy and Gibbs free energy increase with reduction of moisture content of B. capitata (Vahl) Eichler seeds.

2. The enthalpy-entropy compensation theory is valid for the water desorption process in B. capitata (Vahl) Eichler seeds, which is controlled by enthalpy.

3. Desorption of water in B. capitata (Vahl) Eichler seeds is a non-spontaneous process.

\section{ACKNowledgements}

The authors extend thanks to IF Goiano, CAPES, FAPEG, FINEP and CNPq for their financial support, which was indispensable to the execution of this study.

\section{Literature Cited}

Beristain, C. I.; Garcia, H. S.; Azuara, E. Enthalpy-entropy compensation in food vapor adsorption. Journal of Food Engineering, v.30, p.405-415, 1996. https://doi.org/10.1016/ S0260-8774(96)00011-8

Beutler, J. A.; Cardellina, J. H.; McMahon, J. B.; Boyd, M. R.; Cragg, G. M. Anti-HIV and cytotoxic alkaloids from Buchenavia capitata. Journal of Natural Products, v.55, p.207-213, 1992. https://doi. org/10.1021/np50080a008

Brasil. Ministério da Agricultura e Reforma Agrária. Regras para análise de sementes. Brasília: MAPA, 2009. 399p.
Brooker, D. B.; Bakker-Arkema, F. W.; Hall, C. W. Drying and storage of grains and oilseeds. Westport: AVI Publishing Company, 1992. $450 \mathrm{p}$.

Chaves, T. H.; Resende, O.; Oliveira, D. E. C. de; Smaniotto, T. A. de S.; Sousa, K. A. de. Isotermas e calor isostérico das sementes de pinhão-manso. Engenharia na Agricultura, v.23, p.9-18, 2015. https://doi.org/10.13083/1414-3984/reveng.v23n1p9-18

Corrêa, P. C.; Christ, D.; Martins, J. H.; Mantovani, B. H. M. Curvas de dessorção e calor latente de vaporização para as sementes de milho pipoca (Zea mays). Revista Brasileira de Engenharia Agrícola e Ambiental, v.2, p.75-79, 1998. https://doi.org/10.1590/1807-1929/ agriambi.v2n1p75-79

Costa, L. M.; Resende, O.; Oliveira, D. E. C. de; Sousa, K. A. de. Isotermas e calor isostérico de sementes de Buchenavia capitata (Vahl) Eichler. Revista Ciência Agronômica, v.46, p.516-523, 2015. https://doi.org/10.5935/1806-6690.20150033

Goneli, A. L. D.; Corrêa, P. C.; Oliveira, G. H. H. de; Afonso Júnior, P. C. Water sorption properties of coffee fruits, pulped and green coffee. LWT - Food Science and Technology, v.50, p.386-391, 2013. https://doi.org/10.1016/j.lwt.2012.09.006

Goneli, A. L. D.; Corrêa, P. C.; Oliveira, G. H. H. de; Botelho, F. M. Water desorption and thermodynamic properties of okra seeds. Transaction of the American of Society Agricultural Engineers, v.53, p.191-197, 2010.

Gramosa, N. V.; Freitas, J. V. B. de; Silveira, E. R.; Nunes, E. P.; Silva, W. J. M. da. Volatile constituents of the essential oil from leaves of Buchenavia capitata (Vahl) Eichl. Journal of Essential Oil Research, v.22, p.131-132, 2010. https://doi.org/10.1080/10412 905.2010.9700282

Hassini, L.; Bettaieb, E.; Desmorieux, H.; Torres, S. S.; Touild, A. Desorption isotherms and thermodynamic properties of prickly pear seeds. Industrial Crops and Products, v.67, p.457-465, 2015. https://doi.org/10.1016/j.indcrop.2015.01.078

Krug, R. R.; Hunter, W. G.; Grieger, R. A. Enthalpy-entropy compensation: 1 - Some fundamental statistical problems associated with the analysis of Van't Hoff and Arrhenius data. Journal of Physical Chemistry, v.80, p.2335-2341, 1976a. https:// doi.org/10.1021/j100562a006

Krug, R. R.; Hunter, W. G.; Grieger, R. A. Enthalpy-entropy compensation: 2 - Separation of the chemical from the statistical effect. Journal of Physical Chemistry, v.80, p.2342-2351, $1976 \mathrm{~b}$. https://doi.org/10.1021/j100562a007

Leffler, J. E. The enthalpy-entropy relationship and its implications for organic chemistry. The Journal of Organic Chemistry, v.20, p.1202-1231, 1955. https://doi.org/10.1021/jo01126a009

Madamba, P. S.; Driscoll, R. H.; Buchkle, K. A. Enthalpy-entropy compensation models for sorption and browning of garlic. Journal of Food Engineering, v.28, p.109-119, 1996. https://doi. org/10.1016/0260-8774(94)00072-7

Majd, K. M.; Karparvarfard, S. H.; Farahnaky, A.; Jafarpour, K. Temperature effect of sorption isotherms and thermodynamic characteristics. Food Biophysics, v.8, p.1-11, 2013. https://doi. org/10.1007/s11483-012-9274-Z

Nkolo Meze'e, Y. N.; Ngamveng, J. N.; Bardet, S. Effect of enthalpyentropy compensation during sorption of water vapour in tropical woods: The case of Bubinga (Guibourtia Tessmanii J. Léonard; G. Pellegriniana J. L.). Thermochimica Acta, v.468, p.1-5, 2008. https://doi.org/10.1016/j.tca.2007.11.002 
Oliveira, D. E. C. de; Resende, O.; Campos, R. C.; Sousa, K. A. de. Propriedades termodinâmicas de sementes de tucumã-de-Goiás (Astrocaryum huaimi Mart.). Revista Caatinga, v.27, p.53-62, 2014a.

Oliveira, D. E. C. de; Resende, O.; Chaves, T. H.; Souza, K. A. de; Smaniotto, T. A. de S. Propriedades termodinâmicas das sementes de pinhão-manso. Bioscience Journal, v.30, p.147-157, $2014 \mathrm{~b}$.

Othmer, D. F. Correlation vapor pressure and latent heat data: A new plot. Industrial and Engineering Chemistry, v.32, p.841-856, 1940. https://doi.org/10.1021/ie50366a022

Pottier, M.; Bezerra-Silva, P. C.; Bezerra Filho, C. M.; Silva, A. G. da; Silva, M. V. da; Correia, M. T. dos S.; Navarro, D. M. do A. F. Chemical composition of the essential oil of Buchenavia tetraphylla leaves. Journal of Essential Oil Bearing Plants, v.20, p.240-246, 2017. https://doi.org/10.1080/0972060X.2016.1253506
Resende, O.; Oliveira, D. E. C. de; Costa, L. M.; Ferreira Júnior, W. $\mathrm{N}$. Thermodynamic properties of baru fruits (Dipteryx alata Vogel). Engenharia Agrícola, v.37, p.739-749, 2017. https://doi. org/10.1590/1809-4430-eng.agric.v37n4p739-749/2017

Silva, H. W. da; Costa, L. M.; Resende, O.; Oliveira, D. E. C. de; Soares, R. S.; Vale, L. S. R. Thermodynamic properties of pepper seeds - variety 'Cabacinha'. Científica, v.44, p.14-22, 2016. https://doi. org/10.15361/1984-5529.2016v44n1p14-22

Sousa, K. de A.; Resende, O.; Carvalho, B. de S. Determination of desorption isotherms, latent heat and isosteric heat of pequi diaspore. Revista Brasileira de Engenharia Agrícola e Ambiental, v.20, p.493-498, 2016. https://doi.org/10.1590/1807-1929/ agriambi.v20n5p493-498

Weaver, P. L. Buchenavia capitata (Vahl.) Eichler: Granadillo. New Orleans: USDA Forest Service Southern Research Station, 1991. 7p. 